\title{
MOLECULAR AND GENETIC CHARACTERIZATION OF AVIAN LARYNGOTRACHEITIS VIRUS ISOLATES OBTAINED IN UKRAINE
}

\author{
A. L. Veretsun, B. T. Stegniy, O. M. Rula, V. I. Bolotin, \\ A. B. Stegniy, A. P. Gerilovych, D. V. Muzyka \\ National Scientific Center «Institute of Experimental and Clinical Veterinary Medicine» NAAS \\ 83, Pushkinska Str, Kharkiv, Ukraine, 61023 \\ E-mail:dmuzyka77@gmail.com
}

Received February 06, 2021 / Received March 05, 2021 / Accepted March 19, 2021

\begin{abstract}
Aim. To conduct a virological, PCR, PCR-RFLP and sequencing study of infectious laryngotracheitis virus (ILTV) isolates obtained from sick and dead chickens at industrial and backyard poultry farms in the eastern region of Ukraine collected over the years 2010-2019 and to establish their pathotype and relationship with internationally occurring strains. Methods. Material for virological studies was collected in the framework of research program of the NSC IECVM during 2010-2019 in the poultry farms in the North-Eastern region of Ukraine, where the birds with the respiratory clinical signs were found. In total, 28 poultry farms were observed. ILTV isolates were obtained with conventional methods, using 10-12-day-old chicken embryos. A $0,2 \mathrm{ml}$ of 10-20\% suspension of pathological material in PBS was used for inoculation. For in-depth studies, we used 4 isolates of ILTV obtained from sick and dead chickens from industrial and backyard poultry farms in Kharkiv, Luhansk, Donetsk, and Sumy regions from 2010-2019. The identification of ILTV isolates was performed via conventional PCR. The pathotype of ILTV strains was determined using PCR-RFLP (polymerase chain reaction - restriction fragment length polymorphism) analysis. The PCR-RFLP was performed at Royal GD, the Netherlands. The (partial) sequencing of the US8 gene was performed using Sanger sequencing method. The phylogenetic analysis, using sequences of 2 Ukrainian strains (MZ323228, MZ333273) and 17 international gene sequences present in GenBank, was performed using the Maximum Likelihood method. For comparative analysis, sequences of vaccine ILT virus strains were used. Results. Over the years 2010-2019, 7 isolates of ILTV were obtained from sick and dead poultry with typical clinical signs and internal lesions at industrial and backyard farms of the Kharkiv, Donetsk, Luhansk and Sumy regions, and the Autonomous Republic of Crimea. Other avian respiratory viral and bacterial pathogens were not detected. Five isolates were obtained from poultry of industrial holdings where vaccination against ILT is carried out. Using PCR-RFLP analysis of 4 isolates, we found that three of them (Sumy 6-11/19, A 04-12, B 2-10) to belong to vaccine-type ILTV strains and only one, B 59-11 strain, belongs to wild-type ILTV. Vaccine-type ILTV strains circulated and possibly still circulate in Ukraine in industrial and backyard poultry farms among both vaccinated and nonvaccinated poultry. An ILTV wild-type strain was obtained from non-vaccinated chickens from a backyard farm, which may indicate an important role of backyard farms in maintaining the circulation of the virus. After partial sequencing and phylogenetic analysis of the ILTV US8 gene the two Ukrainian strains studied were placed into two different clusters: The vaccine-type B 2-10 strain, obtained from sick vaccinated chickens from an industrial farm, was close to vaccine-type strains circulating in, China, Italy and the USA. The wild-type B 59-11strain, obtained from sick non-vaccinated backyard chickens, was located in another cluster and closest to a the wild-type B 59-11 ILTV strain from Brazil. Conclusions. In this article we describe for the first time the characterization of vaccine-type and wild-type isolates of ILTV in industrial and backyard poultry farms, proving their relevance for the poultry production in Ukraine. The results obtained show the need and prospects for further monitoring of ILTV circulation in small backyard poultry farms and in industrial poultry farms, especially following the frequent use for vaccination of live attenuated wild-type ILTV strains in Ukraine. Further molecular, phylogenetic and epidemiological characterization of the strains obtained should be performed in the near future to further precise their attributes, epidemiology and origin.
\end{abstract}

Key words: infectious laryngotracheitis virus (ILTV), vaccine-type isolates, wild-type isolates, epizootological monitoring.

DOI: https://doi.org/10.15407/agrisp8.01.037

(C) A. L. VERETSUN, B. T. STEGNIY, O. M. RULA, V. I. BOLOTIN, A. B. STEGNIY, A. P. GERILOVYCH, D. V. MUZYKA, 2021 


\section{INTRODUCTION}

Poultry is one of the leading branches of economy both in Ukraine and globally (Polehenka, 2019). In general, infectious diseases are among the most important problems of industrial poultry breeding in Ukraine and in the whole world. Despite enormous efforts in studying the biology of disease agents, elaborating novel ways of early diagnostics and specific prophylaxis, outbreaks of infectious viral and bacterial diseases are registered in different countries almost every year (OIE, 2021). Unfortunately, it is impossible to fully eradicate infectious diseases in animal population, they will constantly accompany living organisms in nature. Therefore, the only way out is continuous monitoring of the circulation of pathogens, depth study of its with constant improvement of diagnostic and preventive methods such as vaccination.

Avian respiratory viral diseases, frequently complicated with bacterial infections which aggravate the clinical course of the main disease, cause on a global scale increasing economic losses (Bakaletz, 1995). Among these respiratory diseases is infectious laryngotracheitis (Gowthaman et al, 2020), (ILT), - a contagious viral disease of chickens of different age, the clinical course of which is similar to that of a respiratory infection (Stegniy, 2013). Though chickens are the main hosts of the infection (Bagust, 1986), the natural disease was registered in peacocks and pheasants (Crawshaw et al, 1982). Other birds such as crows, pigeons, starlings, sparrows and ducks are resistant to this infection (Saif et al, 2008). The disease causes additional industrial expenses, thus decreasing economic efficiency and increasing the losses via higher morbidity and mortality among poultry, a decrease in egg productivity, expenses for required veterinary, sanitary, therapeutic, and preventive measures, targeted at reducing secondary infections (Jones, 2010; Saif et al, 2008; Ou et al, 2012).

The agent of infectious laryngotracheitis is a DNAcontaining herpesvirus (Gallid herpesvirus 1, GaHV-1), which belongs to Iltovirus genus, subfamily Alphaherpesviridae, family Herpesviridae (Davison et al, 2009). GaHV-1 or ILT virus (ILTV) has a high tropism to mucosa cells of upper respiratory passages and eyes. In some cases, the mortality rate may exceed $70 \%$. ILT is frequently complicated with different bacterial infections, thus aggravating the clinical course of the infection in birds and increasing its mortality (Ou et al, 2012).

According to the data of the OIE, from 2009-2019, ILT was registered in 52 countries of the world, includ- ing countries with developed poultry breeding Brazil, Canada, China, Mexico and the USA. As for Europe, during the same period ILT was reported from Austria, Denmark, Finland, Germany, Hungary and Ireland. Although the disease and its agent have long been known (since 1925-1932 (Saif, 2008)., its relevance is still not diminished, so it is necessary to have continuous epizootological monitoring of ILTV circulation at poultry farms, when detected its isolation, and the study of biological, molecular-genetic traits, the elaboration of novel ways of diagnostics and specific prophylaxis (Gowthaman et al, 2020).

As for Ukraine, our country has rather developed industrial poultry. Ukraine is among global leaders by its poultry production volumes and their export (Soiuz ptakhivnykiv Ukrainy, 2021; The State Statistics Service of Ukraine 2021) Ukraine is currently (data for May 2021) free from acute avian infectious diseases, except for some regions with recently registered cases of the highly pathogenic avian influenza in wild birds (OIE, 2021, SSUFSCP, 2021) Industrial poultry farms generally comply strictly with current veterinary and sanitary norms, which ensures reliable control over the epizootic situation. As for backyard farms, they do not always meet requirements, leading to outbreaks of infectious diseases in backyard farm poultry. ILT is not a new infection for Ukraine. It was first registered in this country in 1932 (Babkyn, 1975). The spreading of ILT started with the development of industrial poultry breeding. A widespread incidence of ILT was registered in the 1970-80s, when it was often detected at large industrial poultry breeding farms (Babkyn, 1975; Babkyn et al, 1986; Babkyn et al, 1997). According to the data of the serological and virological monitoring of ILT in Ukraine (Stegniy, 2013) the circulation of this agent was registered at poultry farms in different regions within the recent decade, including the isolation of the ILTV: in the Kharkiv region - in 2010-2012, in the Luhansk region - in 2010 (Stegniy et al, 2013), in the Autonomic Republic of Crimea - in 2011, 2012 (Stegniy and Vorotylova, 2013) in the Donetsk region in 2012 (Muzyka et al , 2018) and in Sumy region - in 2019 (Veretsun, 2021).

Nowadays it is important not only to isolate, identify the pathogen that causes the disease in birds, but also to study its genetic structure. This allows to establish the origin of the pathogen, its relationship with the pathogens from other regions, to accurately establish the pathogenicity of the pathogen, to identify mutations and predict changes in antigenic structure that 
these mutations can cause. With regard to ILT, there are a large number of methods that can quickly and efficiently identify, type and estimate the genetic characteristics of the virus. Thus, real-time PCR, as well as other modifications of PCR, allows detect ILT virus in pathological material rapidly, PCR-RFLP gives possibility to designate a pathotype the virus and determine which type the pathogen belongs to (vaccine or wild type). Sequencing, both classical and NGS allow obtaining a full-length sequence, to conduct phylogenetic analysis, to detect mutations and nucleotide substitutions in genes, to predict changes in the antigenic structure of the virus.

Therefore, ILT is a relevant pathogen for Ukrainian poultry breeding, but the biological and molecular-genetic traits of its pathotypes (vaccine-type or wild-type) occurring, have not been determined yet, nor their origin determined. So, the main aim of this study was to conduct pathotyping of ILTV isolates i.e. to determine their belonging to vaccine-type or wild-type isolates by PCR-RFLP and (partial) sequencing of the US8 gene, circulating in Ukraine from 2010-2019.

\section{MATERIALS AND METHODS}

Virological studies. The studies were conducted at the Department of Poultry Diseases of the National Scientific Center "Institute of Experimental and Clinical Veterinary Medicine" (NSC IECVM). Prior to the study, tissue materials (lung, trachea, spleen) were kept at $-80{ }^{\circ} \mathrm{C}$. The virological studies were conducted by conventional methods (OIE, 2021; Williams et al, 2016): a 10-20\% suspension of the pathological material, obtained from dead poultry in PBS ( $\mathrm{pH} 7.2-7.4)$ with the addition of antibiotics (200 U penicillin, 0.200 $\mathrm{mg}$ streptomycin, $100 \mathrm{U}$ polymyxin, $0.250 \mathrm{mg}$ gentamicin, and $50 \mathrm{U}$ nystatin per $\mathrm{ml}$ ) was used. Prior to inoculation, the above-mentioned suspension was centrifuged at 1,500 rpm for $15 \mathrm{~min}$. The inoculation of 0.2 $\mathrm{ml}$ suspension was made with 10-12-day-old chicken embryos. The inoculation was made onto the chorionallantoic envelopes in the dose of $0.2 \mathrm{ml}$. After inoculation, embryos were incubated at $37{ }^{\circ} \mathrm{C}$ for 7 days.

Virus isolates. Seven ILT isolates: B 2-10 (Kharkiv region), ChP 96-10 (Luhansk region), B 59-11 (Kharkiv region), Kh 2-12 (Kharkiv region), KDS (AR of Crimea), A 04-12 (Donetsk region), Sumy 6-11/19 (Sumy region), obtained from sick and dead chickens at industrial and backyard poultry farms in 2010-2019 were used.

Molecular-genetic studies. The nucleic acids were extracted using a commercial set AmpliSens ${ }^{\circledR}$ DNA-
sorb-B (Russian Federation). PCR was conducted according to previously described methodologies (Kirkpatrick et el, 2006). A region of $2.24 \mathrm{kbp}$ of the thymidine kinase gene of ILTV was amplified with the following primers: $\mathrm{F}\left(5^{\prime}\right.$-CTGGGC-TAA-ATC-ATCCAA-GAC-ATC-A-3') and R (5'-GCT-CTC-TCGAGT-AAGAAT-GAG-TAC-A-3'). The PCR products were separated by electrophoresis in a $0.8 \%$ agarose gel, stained with ethidium bromide and visualized in the UV-transilluminator (Biorad 2000, Germany). The number of repeats, positive and negative controls was according to the PCR protocol (OIE, 2021).

The pathotype determination belonging to wild-type or vaccine-type isolates of ILT was determined in the commercial laboratory Royal GD (Deventer, the Netherlands) by PCR-RFLP-according to the OIE recommendations (OIE, 2021).

The contamination of ILT isolates by other viruses was eliminated using the conventional PCR and primer systems, recommended by the OIE to detect the genome of Newcastle disease virus (NDV), avian influenza virus (AIV) infectious bronchitis virus (IBV), Gumboro disease virus (GDV), metapneumovirus infection (MPV) (OIE, 2021). The control of the contamination with bacterial pathogens was done according to national standard (DSTU 4483 : 2005). In briefly material was inserted in $1 \mathrm{ml}$ in 10 tubes with thioglycolate medium with the further incubation during 14 days at two temperatures: 5 tubes were incubated at a temperature between 30 to $35{ }^{\circ} \mathrm{C}$ to detect aerobic and anaerobic bacteria, and 5 tubes at a temperature between 20 to $25^{\circ} \mathrm{C}$ to detect micromycetes spp. All tubes were checked periodically under diffused light. Sequencing and phylogenetic analysis. Two isolates were selected for sequencing: B 59-11, isolated from a sick unvaccinated chicken from a backyard farm in the Kharkiv region in 2011 and B 2-10, isolated from a sick vaccinated chicken from an industrial farm in Kharkiv region in 2010. A 522 bp sequence in the US8 gene, encoding the envelope glycoprotein E of ILTV was amplified using specific primers and Invitrogen Superscript III One-Step RT-PCR with Platinium Taq set (ThermoFisher Scientific, Waltham, USA). InnuPREP PCRpure Kit (Analytikjena, Germany) was used for purification of DNA before sequencing. The amplicons were sequenced by Sanger technology at the National Veterinary Research Institute (Pulawy, Poland). Multiple alignment was done in ClustalW (MEGA X), and the phylogenetic tree was built in MEGA X. The evolutionary analysis was conducted by Maximum 
Likelihood method in MEGA X (Kumar et al, 2018). Seventeen nucleotide sequences (U28832, JN580315, DQ825435, HM230769, HQ630064, JX104557, JX45 8822, KP677883, KU128407, MN335811, KR822401, MG775218, MH937566, MF405080, EU675324, EU 076288, EU076286) of globally occurring ILTV strains available in GenBank were used in the studies for comparison with the sequences of our two Ukrainian isolates ILTV (MZ323228, MZ333273).

\section{RESULTS}

Seven isolates of ILT virus were obtained at the NSC IECVM, using the pathological material from sick chickens showing pathoanatomical symptoms of ILT, collected from 2010-2019 in 5 different regions of Ukraine (Table 1).

Most virus isolates (5 out of 7) - B 2-10, ChP 9610 , Kh 2-12, KDS, A 04-12 - were isolated from poultry, kept at industrial poultry farms and only two isolates (B 59-11 and Sumy/6-11/19) - from poultry, kept at backyard farms. Five isolates (B 2-10, ChP 9610 , Kh 2-12, KDS, Sumy 6-11/19) were isolated from poultry, vaccinated against ILTV (Gallivac LT, CEVAC, Nobilis ILT, Vectormune, and other). Only two isolates (B 59-11 and A 04-12) originated from sick chickens, non-vaccinated.
The molecular-genetic analysis of the Ukrainian ILTV strains was conducted in three stages.

During the first stage, conventional PCR was used for the primary identification of isolates and for proving the absence of other avian viruses. In PCR, using specific primers, all seven isolates were identified as ILTV. It was also determined that these isolates did not contain the following other avian viral agents: Newcastle disease virus (NDV), avian influenza virus (AIV), infectious bronchitis virus (IBV), Gumboro disease virus (GDV), metapneumovirus infection (MPV) (Table 2). The absence of bacterial contamination was confirmed with the results of bacteriological studies.

The second stage involved determining the pathotype of four ILTV isolates (Sumy 6-11/19, A 04-12, B 59-11 and B 2-10) i.e. their belonging to vaccine-type or wildtype isolates of ILTV. These studies were conducted at the Royal GD company, Deventer, the Netherlands. The results are presented in Table 3.

Therefore, we determined that in 2010-2019 different isolates of infectious laryngotracheitis virus circulated in Ukraine. Three out of four ILTV isolates, involved in the determination of the pathotype, were vaccine-type isolates and only one was a wild-type isolate. It should be noted that all the vaccine-type viruses were isolated from sick and dead chickens from industrial poultry

Table 1. The list of ILT virus isolates, obtained in Ukraine in 2010-2019 at poultry farms

\begin{tabular}{|c|c|c|c|c|c|}
\hline Isolate name & Farm location & Year & $\begin{array}{l}\text { Age of birds, } \\
\text { productivity direction }\end{array}$ & Type of farm & $\begin{array}{c}\text { The } \\
\text { information } \\
\text { about } \\
\text { vaccination } \\
\text { of poultry }\end{array}$ \\
\hline B 2-10 & $\begin{array}{l}\text { Farm } 1 \\
\text { Kharkiv region }\end{array}$ & 2010 & 180 days, layers & Small industrial* & Vaccinated \\
\hline ChP 96-10 & $\begin{array}{l}\text { Farm } 2 \\
\text { Luhansk region }\end{array}$ & 2010 & 125-433 days, layers & Small industrial & Vaccinated \\
\hline B $59-11$ & $\begin{array}{l}\text { Farm } 3 \\
\text { Kharkiv region }\end{array}$ & 2011 & 120 days, meat-and-egg & Backyard** & Unvaccinated \\
\hline Kh 2-12 & $\begin{array}{l}\text { Farm } 4 \\
\text { Kharkiv region }\end{array}$ & 2012 & $\begin{array}{l}\text { 189-193 days, layers, High Line } \\
\text { white cross-breed }\end{array}$ & Small industrial & Vaccinated \\
\hline KDS & $\begin{array}{l}\text { Farm } 5 \\
\text { AR of Crimea }\end{array}$ & 2012 & 150-162 days, layers & Small industrial & Vaccinated \\
\hline A $04-12$ & $\begin{array}{l}\text { Farm } 6 \\
\text { Donetsk region }\end{array}$ & 2012 & $\begin{array}{l}138 \text { days, layers, Dekalb white } \\
\text { cross-breed }\end{array}$ & Small industrial & Unvaccinated \\
\hline Sumy/6-11/19 & $\begin{array}{l}\text { Farm } 7 \\
\text { Sumy region }\end{array}$ & 2019 & 130 days, layers & Backyard & Vaccinated \\
\hline
\end{tabular}

Note. * - a small industrial farm - a farm, keeping a small number of poultry (up to 1,000 birds) in the facilities, adjusted for the sale of poultry products, ** - backyard farm - a farm of private citizens, where a small number of poultry is kept (not more than 100 birds) for personal use. 
farms, where scheduled vaccination against ILT is conducted. The wild-type strain was obtained from dead chickens from the backyard poultry farm in Kharkiv region, where vaccination is not performed.

The third stage of the studies involved sequencing of a part of the US8 gene of ILTV wild-type-like isolate B 59-11 and vaccine-like isolate B 2-10. Taking into account the fact that ILTV has a large genome (n $150,118-153,648 \mathrm{bp}$ ) we limited ourselves to have the US8 gene only partially sequenced (522 bp) The region selected encodes the envelope glycoprotein E of infectious laryngotracheitis virus (Gowthaman, 2020). After sequencing and obtaining the nucleotide sequence, we conducted the phylogenetic analysis to determine the phylogenetic relations between these two Ukrainian isolates of the two ILTV strains. (Figure).

Based on partial sequencing of the US8 gene the two Ukrainian ILTV strains and phylogenetic analysis of their sequences, these two strains were shown to be present in different clusters. The vaccine-type strain B 2-10 (obtained from vaccinated poultry) was placed into a large cluster with both wild-type and vaccinetype strains, originating from different countries in the world (including China, Italy and the USA). This Ukrainian strain was closest to the epizootic virus strain US10 originating from the USA and also used in the USA as a reference strain (Wild, Cook et al, 1996). As for the wild-type isolate B 59-11 (obtained from nonvaccinated poultry), it was placed in a separate cluster together with a wild-type ILTV strain originating from Brazil.

\section{DISCUSSION}

A key moment in controlling infectious agents is obtaining them from sick or dead poultry to be able to perform further study of biological and moleculargenetic and epidemiological properties. Regardless of modern diagnostics and an extensive vaccination program, used in industrial poultry breeding, ILT remains an important problem. This disease has been present in industrial poultry breeding of Ukraine for many years (Babkyn et al, 1997; Babkyn et al, 1986; Babkyn et al, 1975) and there are also recent records. For instance, the studies of N.G. Vorotylova and B.T. Stegniy demonstrated the presence of specific antibodies to ILTV at industrial poultry farms (Stegniy and Vorotylova 2013, Stegniy et el, 2013), later antibodies to ILTV were also found in poultry from backyard poultry-breeding farms (Muzyka et al, 2018, Veretsun et al, 2021). The results of serological monitoring were confirmed with the isolation of the disease agent from pathological material (Stegniy et al, 2013; Stegniy and Vorotylova 2013; Muzyka et al, 2018; Veretsun et al, 2021). In addition,

Table 2. The results of identification of ILTV isolates, and absence of other avian respiratory viruses in clinical material from sick and dead poultry with the damage to the respiratory system

\begin{tabular}{l|c|c|c|c|c|c}
\hline \multirow{2}{*}{ Isolate } & \multicolumn{7}{c}{ PCR result } \\
\cline { 2 - 7 } & ILTV & NDV & IBV & GDV & MPV & AIV \\
\hline B 2-10 & + & - & - & - & - & - \\
ChP 96-10 & + & - & - & - & - & - \\
B 59-11 & + & - & - & - & - & - \\
Kh 2-12 & + & - & - & - & - & - \\
KDS & + & - & - & - & - & - \\
A 04-12 & + & - & - & - & - & - \\
Sumy/6-11/19 & + & - & - & - & - & - \\
Positive PCR control for specific pathogens* & + & + & + & + & + & + \\
Negative control & - & - & - & - & - & - \\
\hline
\end{tabular}

Note. + - the presence of a specific fragment. * - vaccine and/or reference strain from collection of NSC IECVM

Table 3. The results of determining the pathotype of four Ukrainian isolates of ILTV

\begin{tabular}{c|l|c}
\hline Isolate & \multicolumn{1}{|c}{ Place and year of isolation } & Pathotype \\
\hline Sumy 6-11/19 & Sumy region, 2019, backyard & Vaccine-type \\
A 04-12 & Donetsk region, 2012, small industrial farm & Vaccine-type \\
B 59-11 & Kharkiv region, 2011, backyard farm & Wild-type \\
B 2-10 & Luhansk region, 2010, industrial farm & Vaccine-type \\
\hline
\end{tabular}


the specificities of ILTV biology, the ability of latent infection, and recombination of wild-type and vaccinetype viruses lead to the occurrence of new isolates, which may be more pathogenic (Fakhri et al, 2020).

While analyzing data of our scientific research regarding the epizootic situation with ILT in Ukraine, it is possible to say that ILTV circulation among backyard poultry in Ukraine is still present up till now. According to the official data of the State Service of Ukraine on Food Safety and Consumer Protection, no cases of ILT disease have been recently registered at industrial poultry farms (SCUFSCP, 2021). Still, the presence of the virus, especially at small backyard farms may not be ruled out. The isolate of ILTV, obtained by us from the backyard farm in Sumy region in 2019, may serve as proof. While analyzing the results of virological studies over the last ten years in Ukraine, it should be noted that a certain, although low, circulation of the virus was determined both at industrial and homestead poultry farms in different regions of Ukraine. The determination of virulent virus strains (wild-type and vaccine-type) circulation among vaccinated chickens is of no less relevance.

Using the results of joint studies, the determination of the pathotype of two ILTV virus strains is published here for the first time in Ukraine, and it demonstrates that both vaccine- type and wild-type isolates of the virus circulate at poultry farms. It is noteworthy that vaccine-type strains of ILTV were obtained not only from the vaccinated chickens from industrial farms (isolate B 2-10) but also from unvaccinated chickens (isolate A 04-12). This information demonstrates that pathogenic vaccine-type strains of ILTV are capable of spreading among poultry farms which may be promoted by latent ILT infection (Thilakarathne et al, 2019; Fakhri et al, 2020).

The obtaining of the ILTV wild-type isolate from unvaccinated chickens at backyard farms also demonstrates active circulation of ILT virus among backyard farms and the fact that homestead farms, where veterinary and sanitary requirements are not always met, may play an important role in maintaining the circulation of pathogenic ILT isolates. These results of our studies are in agreement with the data of other researchers from Ethiopia and Iraq (Odisho et al, 2015; Roba et al, 2020).

The obtained results are in line with large-scale studies of ILTV, which were conducted in Western Europe, where the wild-type isolates were found in backyard birds, while similar vaccine viruses were isolated from the vaccinated flocks (Neff et al, 2008).
Many authors from all over the world reported the importance of ILT as a problem for poultry farms. In Southeast Asia and North Africa, where poultry farming is one of the important branches of the economy, the circulation of the ILTV was also confirmed (Yang et al, 2020; Bayoumi et al, 2020). In addition, circulation of the vaccine strains was also detected by Bayoumi et al, 2020 .

The results of the ILTV isolation and its pathotyping that were conducted in different countries of the world along with our previous results prove the necessity of in-depth study of the ILTV in Ukraine and further studies are needed.

We report here for the first time the partial sequencing of two Ukrainian ILTV strains (wild- and vaccinetype). The phylogenetic analysis demonstrated different relations of these strains, the vaccine-type strain with American/China/Italy strains and the wild-type strain with a Brazilian strain. Our phylogenetic study highlights also an urgent need to continue the monitoring of this disease, conducting complete genome sequencing of Ukrainian ILTV strains for more in-depth studies to determine relationships, epidemiology and origin. The relevance of conducting molecular-genetic studies is related to the fact that it helps determine the possible recombinations and back-mutations of vaccine-type strains, which, at the end, may lead to the occurrence of novel, more virulent disease agents as compared with their parental strains (Piccirillo et al, 2016). Such studies were conducted in Australia (Blacker et al, 2011), the USA (Oldoni et al, 2007), Italy (Piccirillo et al, 2016), China (Zhao et al, 2015), Korea (La et al, 2019). The results of these studies demonstrate that the circulating epizootic isolates are often genetically related to the attenuated vaccine-type strains produced using chicken embryos and in some cases, to recombinant vaccine-type strains (Norberg et al, 2015). It should be noted that this direction of the studies is also important for Ukraine, because many different vaccines are used in this country, including the ones, based on attenuated strains of ILTV.

The relevance of monitoring the circulation and obtaining of ILTV isolates at poultry farms of Ukraine is also related to the possibility to further use these local (inactivated) strains as industrial strains to produce vaccines for specific ILT prophylaxis (Ebrahimi et al, 2020).

\section{CONCLUSIONS}

In this article we describe for the first time the characterization of vaccine-type and wild-type isolates of 


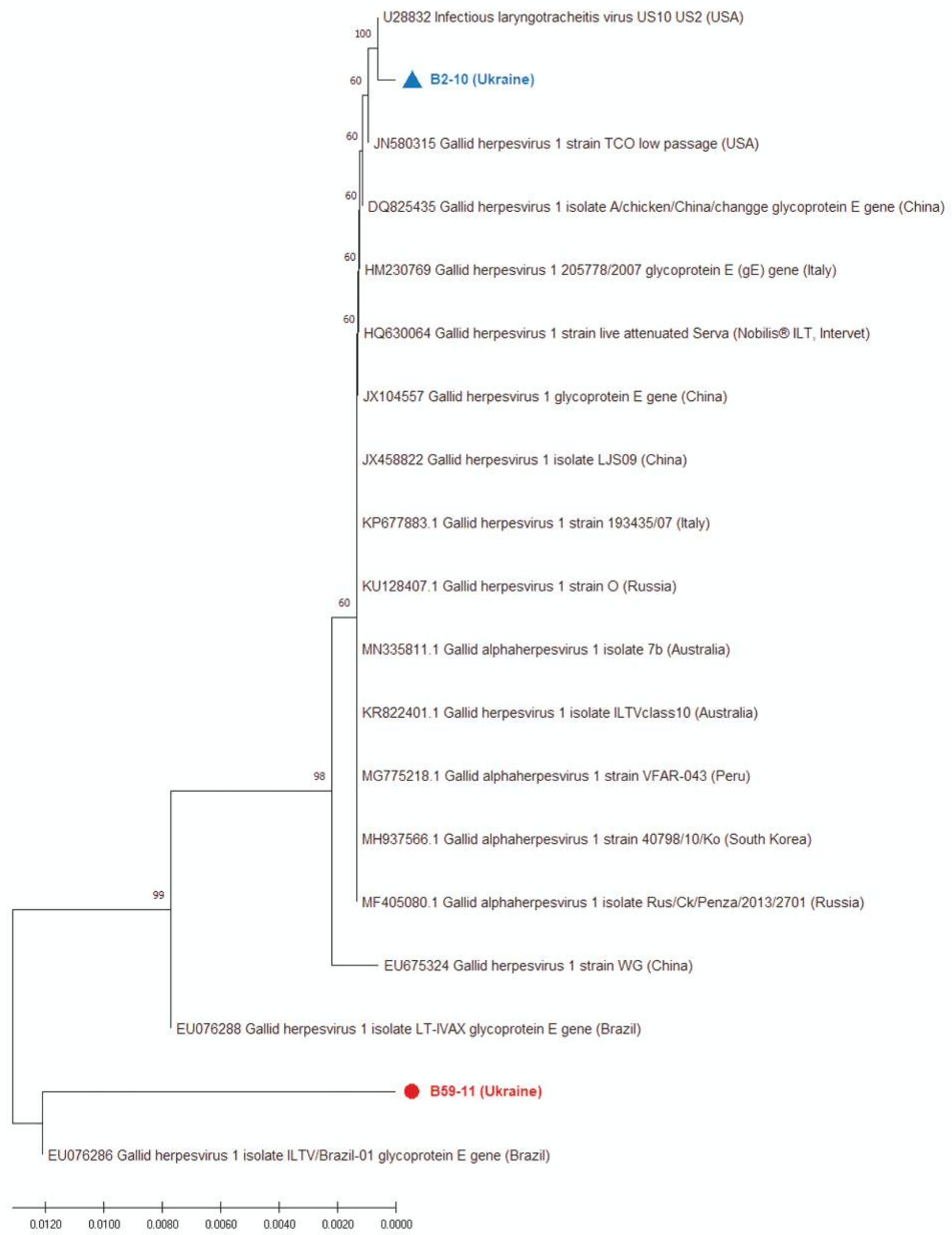

Phylogenetic relations of two Ukrainian ILTV strains (one from an industrial farm (B2-10), vaccine-type and one from a backyard farm, wild-type (B59-11) when compared with 17 internationally available partial sequences of the US8 gene, present in GenBank (NJ, Bootstrap 1000). Note: • $\mathbf{\Delta}$ - Ukrainian isolate, investigated in this study 
ILTV virus in industrial and backyard poultry farms, proving their relevance for the poultry production in Ukraine. The results obtained show the need and prospects for further monitoring of ILTV circulation in small backyard poultry farms and in industrial poultry farms, especially following the frequent use for vaccination of live attenuated wild-type ILTV strains in Ukraine. Further molecular, phylogenetic and epidemiological characterization of the strains obtained should be performed in the near future to further precise their attributes, epidemiology and origin.

Adherence to ethical principles. No experimental animals were used in the studies. The pathological material, obtained from dead poultry, was used. All the studies involving the use of chicken embryos were conducted in accordance with international ethical principles. The methods of virological studies were reviewed and approved at the meeting of the Bioethics Commission of NSC IECVM.

Conflict of interest. Authors declare no conflict of interest.

Financing. This study was funded within the framework of the State Scientific Program of the NAAS of Ukraine (\#26.3-01.01.1 and \#38.01.02.02). The authors would like to express their gratitude to the scientists of the National Veterinary Research Institute (Pulawy, Poland) and the commercial company, Royal GD (Deventer, the Netherlands) for their cooperation and taking part in the characterization of our ILTV strains.

\section{Молекулярно-генетичні властивості ізолятів вірусу інфекційного ларинготрахеїту, виділених в Україні}

А. Л. Верецун, Б. Т. Стегній, О. М. Рула, В. І. Болотін, А. Б. Стегній, А. П. Герілович, Д. В. Музика

Національний науковий центр «Інститут експериментальної і клінічної ветеринарної медицини», вул. Пушкінська, 83, Харків, Україна, 61023

E-mail: dmuzyka77@gmail.com

Мета. Провести вірусологічні та молекулярно-генетичні дослідження ізолятів вірусу інфекційного ларинготрахеїту (ІЛТ), які ізольовані від хворої та загиблої птиці у птахівничих господарствах України у 20102019 pp., встановити їх патотип і походження. Методи. Матеріал для вірусологічних досліджень було зібрано в рамках наукових досліджень ННЦ «ІЕКВМ» у 20102019 pp. в птахівничих господарствах України, де у птиці реєструвалися респіраторні клінічні ознаки. Всього було досліджено 28 птахівничих господарств. Виділення ізолятів вірусу ІЛТ проводили за загально- прийнятими методиками 3 використанням 10-12 добових курячих ембріонів. Для інфікування використовували 10-20\% суспензію патологічного матеріалу в дозі 0,2 мл. Для поглиблених досліджень було використано 4 ізоляти вірусу інфекційного ларинготрахеїту, які виділені від хворих і загиблих курей із промислових і присадибних птахівничих господарств Харківської, Луганської, Донецької, Сумської областей і АР Криму в 2010-2019 рр. Ідентифікацію ізолятів вірусу ІЛТ проводили у традиційній ПЛР. Патотип ізолятів вірусу ІЛТ визначали у ПЛР за методом рестрикційного аналізу. Секвенування ділянки гену US8 проведено методом Сенгера. Для порівняльного аналізу, були залучені послідовності вакцинних штамів і польових ізолятів вірусу ІЛТ з різних країн світу, а також послідовності двох українських ізолятів вірусу ІЛТ (MZ323228, MZ333273). Філогенетичний та еволюційний аналіз було проведено за допомогою методу Маximum Likelihood. Результати. У 2010-2019 рр. за результатами вірусологічних досліджень від хворої та загиблої птиці із промислових і присадибних птахівничих господарств Харківської, Донецької, Луганської, Сумської областей та АР Криму з характерними клінічними та патологоанатомічними ознаками ІЛТ виділено 7 ізолятів вірусу ІЛТ. Збудників інших вірусних i бактеріальних патогенів не виявлено. Більшість ізолятів (5 ізолятів) виділена від птиці із промислових господарств, де проводиться вакцинація проти ІЛТ. Поглибленими дослідженнями 4 ізолятів у ПЛР встановлено, що три з них (Summy 6-11/19, А 04-12, Б 2-10) належать до вакциноподібних ізолятів ІЛТ і тільки один ізолят В 59-11 - належить до польових вірусів ІЛТ. Встановлено, що вакциноподібні ізоляти ІЛТ циркулювали в Україні у промислових птахівничих господарствах як серед вакцинованої, так і серед невакцинованої птиці. Польовий ізолят вірусу ІЛТ було виділено від невакцинованих курей із присадибного господарства, що може свідчити про важливу роль саме присадибних господарств у підтриманні циркуляції патогенних польових ізолятів ІЛТ. За результатами секвенування та філогенетичного аналізу ділянки гену вірусу ІЛТ встановлено розташування українських ізолятів у двох окремих кластерах: вакциноподібний ізолят Б 2-10, що ізольований від хворих вакцинованих проти ІЛТ курей із промислового господарства увійшов до великого кластеру, в якому розташовані як польові, так i вакцинні віруси, що циркулювали в різних країнах світу (США, Китай, Італія), у той же час польовий ізолят В 59-11, що виділений від хворих не вакцинованих проти ІЛТ курей із присадибного господарства розташований в окремому кластері та споріднений 3 польовим вірусом ІЛТ, який циркулював у Бразилії. Висновки. Виділення вакциноподібних і польових ізолятів вірусу ІЛТ у промислових і присадибних птахівничих господарствах свідчить про актуальність цього захворювання 
для України. Отримані результати водночас вказують на необхідність та перспективи подальших досліджень 3 інтенсифікації моніторингу циркуляції вірусу ІЛТ у малих присадибних птахівничих господарствах, проведення постійного моніторингу вірусу інфекційного ларинготрахеїту у промислових птахівничих господарствах, особливо на фоні використання живих аттенуйованих вакцин, проведення повногеномного секвенування українських вакциноподібних і польових ізолятів вірусу інфекційного ларинготрахеїту.

Ключові слова: вірус інфекційного ларинготрахеїту (ІЛТ), вакциноподібні ізоляти, польові ізоляти, епізоотологічний моніторинг.

\section{REFERENCES}

Babkyn VF. (1986). Infectious laryngotracheitis. In: Respiratory diseases of domestic animals, Kyiv (In Ukrainian).

Babkyn VF. (1975). Infectious laryngotracheitis of birds, Kyiv (In Ukrainian).

Babkyn VF, Makagon V, German VV. (1997). Vaccine prevention of infectious laryngotracheitis and Newcastle disease in poultry in southern Ukraine. Vet. Med. Ukraine. 12:20-22 (In Ukrainian).

Bagust TJ. (1986). Laryngotracheitis (Gallid-1) herpesvirus infection in the chicken. 4. Latency establishment by wild and vaccine strains of ILT virus. Avian. Pathol. 15:581-595. doi: 10.1080/03079458608436317.

Bakaletz LO. (1995). Viral potentiation of bacterial superinfection of the respiratory tract. Trends Microbiol. 3:110-114. doi: 10.1016/s0966-842x(00)88892-7.

Blacker HP, Kirkpatrick NC, Rubite A, O'Rourke D, Noormohammadi AH. (2011). Epidemiology of recent outbreaks of infectious laryngotracheitis in poultry in Australia. Aust. Vet. J. 89:89-94. doi: 10.1111/j.17510813.2010.00665.x.

Bayoumi M, El-Saied M, Amer H et al. (2020) Molecular characterization and genetic diversity of the infectious laryngotracheitis virus strains circulating in Egypt during the outbreaks of 2018 and 2019. Arch. Virol. 165:661670. doi.org/10.1007/s00705-019-04522-4.

Crawshaw GJ, Boycott BR. (1982). Infectious laryngotracheitis in peafowl and pheasants. Avian. Dis. 26:397-401.

Davison AJ, Eberle R, Ehlers B, Hayward GS, McGeoch DJ, Minson AC, Pellett PE, Roizman B, Studdert MJ, Thiry E. (2009). The order Herpesvirales. Arch.Virol. 154:171177. doi: 10.1007/s00705-008-0278-4.

DSTU 4483:2005 Preparaty veterynarni imunobiologichni. Metody vyznachennja bakterialnoi i grybnoi kontaminacii [Veterinary preparations immuno-biological. Methods of determination of bacterial and fungal contamination]. (2006). DSTU 4483:2005 from 10.01.2006. K.: Derzhspozhyvstandart Ukrainy [in Ukrainian].

Ebrahimi MM, Shahsavandi S, Yousefi AR, Ebrahimi N. (2020). Isolation, identification and chemical inactivation of infectious laryngotracheitis virus for use as a vaccine candidate. Acta Virol. doi: 10.4149/av_2021_101.

Fakhri O, Devlin JM, Browning GF, Coppo MJC, Quinteros JA, Diaz-Mendez A, Lee SW, Hartley CA. (2020) Superinfection and recombination of infectious laryngotracheitis virus vaccines in the natural host. Vaccine. 38:7508-7516. doi: 10.1016/j.vaccine.2020.09.064.

Gowthaman V, Kumar S, Koul M, Dave U, Murthy TRGK, Munuswamy P, Tiwari R, Karthik K, Dhama K, Michalak I, Joshi SK. (2020) Infectious laryngotracheitis: Etiology, epidemiology, pathobiology, and advances in diagnosis and control - a comprehensive review. Vet.Q. 40:140161. doi: 10.1080/01652176.2020.1759845.

Jones RC. (2010). Viral respiratory diseases (ILT, aMPV infections, IB): are they ever under control? Br. Poult. Sci. 51:1-11. doi: 10.1080/00071660903541378.

Kirkpatrick NC, Mahmoudian A, O'Rourke D, Noormohammadi AH. (2006). Differentiation of infectious laryngotracheitis virus isolates by restriction fragment length polymorphic analysis of polymerase chain reaction products amplified from multiple genes. Avian Dis. 50:28-34.

Menendez RK, García M, Spatz S, Tablante NL. (2014) Molecular epidemiology of infectious laryngotracheitis: a review, Avian. Pathol. 43:(2)108-117. doi: 10.1080/030 79457.2014.886004.

Kumar S, Stecher G, Li M, Knyaz C, Tamura K. (2018). MEGA X: Molecular Evolutionary Genetics Analysis across Computing Platforms. Mol. Biol. Evol. 35:15471549. doi: $10.1093 / \mathrm{molbev} / \mathrm{msy} 096$.

La TM, Choi EJ, Lee JB, Park SY, Song CS, Choi IS, Lee SW. (2019). Comparative genome analysis of Korean field strains of infectious laryngotracheitis virus. PLoS.One. 14:e0211158. doi: 10.1371/journal.pone.0211158.

Muzyka DV, Veretsun AL, Stegniy BT, Rula OM, Usova $L P$. (2018) Isolation and identification of epizootic isolate of infectious laryngotracheitis virus (Vydilennya ta identyfikatsiya epizootychnoho izolyatu virusu infektsiynoho larynhotrakheyitu). Veter. Med. 104:37-142 (in Ukrainian]).

Neff C, Sudler C, Hoop RK. (2008) Characterization of western European field isolates and vaccine strains of avian infectious laryngotracheitis virus by restriction fragment length polymorphism and sequence analysis. Avian Dis. 52(2):278-283. doi: 10.1637/8168-110107-Reg.1.

Norberg P, Depledge DP, Kundu S, Atkinson C, Brown J, Haque T, Hussaini Y, MacMahon E, Molyneaux $P$, Papaevangelou V, Sengupta N, Koay ES, Tang JW, Underhill GS, Grahn A, Studahl M, Breuer J, Bergstrom T. (2015) Recombination of Globally Circulating Varicella-Zoster Virus. J. Virol. 89:7133-7146. doi: 10.1128/ JVI.00437-15.

Odisho S, Allawe A, Barhoom S. (2015) Investigation of infectious laryngotracheitis virus in Iraqi chicken farms. Bas. J. Vet. Res. 14(1):302-310.

OIE (2019) Manual of Diagnostic Tests and Vaccines for 


\section{VERETSUN et al.}

Terrestrial Animals. http: https://www.oie.int/fileadmin/ Home/eng/Health_standards/tahm/3.03.03_AVIAN_ INF_LARYNGO.pdf.

OIE (2021) Disease Information. World organization for animal health. URLhttps://www.oie.int/en/animal-healthin-the-world/wahis-portal-animal-health-data/

Oldoni I, Garcia M. (2007) Characterization of infectious laryngotracheitis virus isolates from the US by polymerase chain reaction and restriction fragment length polymorphism of multiple genome regions. Avian Pathol. 36:167-176. doi: 10.1080/03079450701216654.

Ou SC, Giambrone JJ. (2012) Infectious laryngotracheitis virus in chickens. World J. Virol. 1:142-149. doi: 10.5501/wjv.v1.i5.142.

Piccirillo A, Lavezzo E, Niero G, Moreno A, Massi P, Franchin E, Toppo S, Salata C, Palu G. (2016) Full Genome Sequence-Based Comparative Study of WildType and Vaccine Strains of Infectious Laryngotracheitis Virus from Italy. PLoS. One. 11:e0149529. doi: 10.1371/ journal.pone.0149529.

Polehenka M. (2019), "An analysis of the current state of poultry production in Ukraine", Ekonomika ta derzhava. 3:37-143. doi: 10.32702/2306-6806.2019.3.137.

Roba YT, Tadesse D, Assefa Z, Tesfaye A. (2020) Seroprevalence of infectious laryngotracheitis disease in backyard chickens in villages of Ada'a district, Oromia, Ethiopia: first report. Trop. Anim. Health Prod. 52:31093112. doi: 10.1007/s11250-020-02334-2.

Saif YM, Fadly AM. (2008) Diseases of poultry. Blackwell Pub, Ames, Iowa.

Soiuz ptakhivnykiv Ukrainy (2021) Analytical information. URL http://www.poultryukraine.com/ru/poultry/analytics/ 2019/01/analytics_6998.html.

Stegniy B, Vorotylova N. (2013). The Study of Biological Properties of Infectious Laryngotracheitis Virus Isolates Obtained from Chickens in the Autonomous Republic of Crimea. Aktualnye voprosy veterynarnoi biolohii. 4(20): 36-40 (in Russian).

Stegniy BT, Muzyka DV, Rula OM, Stegniy AB, Tkachenko $S V$, Mayorova KF, Usova LP, Poltorackiy EV, Vorotylova $N G$. (2013) Monitoring of Infectious Laryngotracheitis in Ukraine and the World (Monitorynh infektsiynoho larynhotrakheyitu v Ukrayini ta sviti). Veterynarna medytsyna. 97:237-239 (in Ukrainian).
The State Service of Ukraine on Food Safety and Consumer Protection (SSUFSCP) (2021), URL https://dpss.gov.ua/en.

The State Statistics Service of Ukraine (2021) Analytical information. Number of agricultural animals. http://www. ukrstat.gov.ua/

Thilakarathne DS, Coppo MJC, Hartley CA, Diaz-Mendez A, Quinteros JA, Fakhri O, Vaz PK, Devlin JM. (2019) Attenuated infectious laryngotracheitis virus vaccines differ in their capacity to establish latency in the trigeminal ganglia of specific pathogen free chickens following eye drop inoculation. PLoS. One. 14:e0213866. doi: 10.1371/journal.pone.0213866.

Veretsun AL, Rula OM, Usova LP, Muzyka DV. (2021) Circulation of infectious laryngotracheitis virus in poultry farms of Ukraine in 2009-2020. Veterynarna biotehnologija - Veterinary biotechnology. 38:21-35. https://doi. org/10.31073/vet_biotech38-02.

Vorotylova NG. (2014) Epizootological monitoring of highly pathogenic influenza, infectious laryngotracheitis of birds and biological properties of the pathogen, Kharkiv. (In Ukrainian).

Wild MA, Cook S, Cochran M. (1996) A genomic map of infectious laryngotracheitis virus and the sequence and organization of genes present in the unique short and flanking regions. Virus Genes. 12:107-116. doi: 10.1007/ BF00572949.

Williams S. (2016) A laboratory manual for the isolation, identification and characterization of avian pathogens. Athens, GA: American Association of Avian Patho-logists.

Yan Z, Li S, Xie Q, Chen F, Bi Y. (2016). Characterization of field strains of infectious laryngotracheitis virus in China by restriction fragment length polymorphism and sequence analysis. J. Veter. Diagn. Invest. 28(1):46-49. doi: $10.1177 / 1040638715618230$.

Yang Z, Murata S, Fujisawa S et al. (2020) Molecular detection and genetic characterization of infectious laryngotracheitis virus in poultry in Myanmar. BMC Vet. Res. 16:453. https://doi.org/10.1186/s12917-02002666-Z.

Zhao Y, Kong C, Wang Y. (2015) Multiple Comparison Analysis of Two New Genomic Sequences of ILTV Strains from China with Other Strains from Different Geographic Regions. PLoS. One. 10:e0132747. doi: 10. 1371/journal.pone.0132747. 